\title{
An opportunity for testing multiple paternity in a wild Jaguar (Panthera onca)
}

\author{
Gabriela Medeiros de Pinho ${ }^{1,2,4}$, Rogerio Fonseca ${ }^{3}$ \& Izeni Pires Farias ${ }^{1}$ \\ ${ }^{1}$ Departamento de Biologia, Universidade Federal do Amazonas, Manaus, AM, Brazil. \\ ${ }^{2}$ Department of Ecology and Evolutionary Biology, University of California, Los Angeles, California, \\ United States \\ ${ }^{3}$ Departamento de Ciências Florestais, Universidade Federal do Amazonas, Manaus, AM, Brazil. \\ ${ }^{4}$ Corresponding author: Gabriela Medeiros de Pinho, e-mail: gabriela.m.pinho@gmail.com
}

PINHO, G.M., FONSECA, R., FARIAS, I.P. An opportunity for testing multiple paternity in a wild Jaguar (Panthera onca). Biota Neotropica. 14(3): e20140055. dx.doi.org/10.1590/1676-06032014005514

\begin{abstract}
We performed a paternity test for three cubs from one wild female jaguar (Panthera onca). The opportunity for this study was generated by an accident involving a vehicle collision with a pregnant jaguar in the central Amazon. The cubs are polyzygotic triplets and were found to have been sired by the same male. Here, we also provide an overview and discuss several aspects of jaguar reproduction.
\end{abstract}

Keywords: Felidae, Paternity test, Multiple paternity, Road kill, Amazon.

PINHO, G.M., FONSECA, R., FARIAS, I.P. Uma oportunidade para testar múltipla paternidade em onça selvagem (Panthera onca). Biota Neotropica. 14(3): e20140055. dx.doi.org/10.1590/1676-06032 014005514

Resumo: Nós realizamos um teste de paternidade em três filhotes de uma onça selvagem (Panthera onca). A oportunidade para este estudo foi criada a partir de um acidente envolvendo a colisão entre um veículo e uma onça grávida na Amazônia central. Os filhotes são trivitelinos e foram gerados por um mesmo macho. Neste estudo nós também oferecemos uma revisão e discutimos aspectos da reprodução de onças.

Palavras-chave: Felidae, Teste de Paternidade, Multipla paternidade, Atropelamento, Amazônia.

\section{Introduction}

Felids frequently use roads and trails to move and to find prey (Sunquist 1981), and both male and female jaguars (Panthera onca) use this resource (Rabinowitz \& Nottingham 1986). For researchers, this habit facilitates behavioral and diet studies due to the large number of direct observations and fecal samples found on roads (e.g., Rabinowitz \& Nottingham 1986, Garla et al. 2001). In spite of these advantages, accidental mortality caused by vehicle collision is a serious threat to carnivores with large home ranges (Costa et al. 2005). This work is the result of a paternity test on a female jaguar pregnant with three cubs, that was fatally injured in one such occurrence.

Primary knowledge about reproduction in felids is derived from studies sampling a small number of individuals (e.g. Sadleir 1966a, Soares et al. 2006, Carrillo 2009). These reports, when accumulated, allow us to infer patterns and are particularly important in regard to the jaguar, one of the most difficult large cats to study (Harmsen et al. 2010). Research on captive animals has provided useful evidence such as describing the hormones responsible for oocyte maturation and gestation (Brown 2011), and contributes to the success of assisted reproduction in felines (Morato \& Barnabe 2002, Swanson 2006, Paz et al. 2007). Jointly with the ex situ approach, studies on wild individuals generate precious information for estimating population growth rates and analyzing population viability (Desbiez et al. 2012, Miller 2013).
The felid mating system is often classified as polygynous or promiscuous, but there is a lack of studies on the relationships between individuals (Macdonald et al. 2010). Regarding jaguars, analyses based on the body mass percentage allocated in testes suggest that females rarely breed with more than one male in one estrus (see Azevedo et al. 2006 and Costa et al. 2006 for more details). However, ecological approaches indicate polygamy, where studies have reported females overlapping home ranges with more than one adult male (Rabinowitz \& Nottingham 1986, Soares et al. 2006, Jedrzejewski et al. 2011, Palomares et al. 2012); and two to four males following one female (Hoogesteijn and Mondolfi 1992, Almeida 1976; in Sunquist and Sunquist 2002). Also, males appear not to be territorial in their use of space (Harmsen et al. 2010, Jedrzejewski et al. 2011), but are not usually found to use an area at the same time (Rabinowitz \& Nottingham 1986). In conclusion, the possibility of multiple paternity is still not clear; especially due to the lack of studies on parentage in wild felids (Culver et al. 2010).

Considering the scarce information on the species' reproduction, and the rare opportunities in accessing wild individuals, we analyzed the paternity of three jaguar cubs from one litter in the central Amazon, Brazil. The female was hit by a truck on the Tronco road, close to the Geólogo Pedro Moura operation station $\left(04^{\circ} 53^{\prime} \quad 04.64^{\prime \prime S} ; \quad 65^{\circ} 18^{\prime} \quad 34,61 " \mathrm{~W}\right)$ municipality of Coari, Amazonas, Brazil. The truck was loaded and at a velocity of $60 \mathrm{~km} / \mathrm{h}$. The impact killed the female 
instantaneously, and post-mortem examination revealed a fracture in the left front foot, displacement of the scapula and left ribs (with lung perforation), and damage to the braincase and fracture of the jaw (which caused a cerebral perforation). The female had a total body length of $163 \mathrm{~cm}$, head and thorax circumferences of $48 \mathrm{~cm}$ and $74 \mathrm{~cm}$ respectively, average canine tooth length $3.2 \mathrm{~cm}$, and average foot length of $6 \mathrm{~cm}$ (excluding the claw). Moreover, the female was approximately 3.5 years old, weighting $58.9 \mathrm{~kg}$, and was at the beginning of the second month of gestation-based on the data for the domestic cat from Abreu et al. (2011) — of three cubs.

\section{Material and methods}

The skeleton and skin of the female are deposited in the Paulo Bürnheim Zoology Collection, at the Federal University of Amazonas (UFAM). Tissue samples are stored in Tissue Collection at the Laboratory of Evolution and Animal Genetics at UFAM (CTGA-M 5669; CTGA-M 5670; CTGA-M 5671; CTGA-M 5672). Data were added to the Global Biodiversity Information Facility (http://www.gbif.org/).

We collected tissue samples from the mother and her cubs, and these were stored in absolute ethanol at $-20{ }^{\circ} \mathrm{C}$. DNA was isolated using the QIAmp DNA extraction tissue kit (QIAGEN), following the manufacturer's protocol. We tested 20 microsatellites markers described by Menotti-Raymond et al. (1999) and, from the 12 markers that amplified well, nine were polymorphic and therefore used for the paternity analysis: FCA026, FCA043, FCA075, FCA077, FCA090, FCA193, FCA211, FCA229, FCA678. The primers were labeled with a fluorescent dye using the method described by Schuelke (2000). The polymerase chain reaction conditions were: $93{ }^{\circ} \mathrm{C}$ for $2 \mathrm{~min} ; 35$ cycles of $93{ }^{\circ} \mathrm{C}$ for 5 $\mathrm{s}, 55^{\circ} \mathrm{C}$ for $15 \mathrm{~s}$ and $68^{\circ} \mathrm{C}$ for $1 \mathrm{~min} ; 25$ cycles of $93{ }^{\circ} \mathrm{C}$ for $5 \mathrm{~s}, 50$ ${ }^{\circ} \mathrm{C}$ for $15 \mathrm{~s}$ and $68^{\circ} \mathrm{C}$ for $1 \mathrm{~min}$; followed by $68^{\circ} \mathrm{C}$ for $30 \mathrm{~min}$ and a final hold at $15^{\circ} \mathrm{C}$. Genotyping was performed on an ABI $3130 x 1$ sequencer (Applied Biosystems), using a mix of $1 \mu 1$ of the PCR product, $8 \mu \mathrm{l}$ of formamide and $1 \mu \mathrm{l}$ of the ROX size standard (DeWoody et al. 2004). Allele size was inferred in the program GENEMAPPER v4.0 (Applied Biosystems). The presence of multiple paternity was tested by manual counting of allele number, inferring the father(s) genotype from the comparison between the mother and the cubs genotypes (Figure 1). We also analyzed the data with GERUd 2.0 (Jones 2005), to check for any mistakes in our manual analyses.

\section{Results and discussion}

As shown in the figure 1, there is no evidence for multiple paternity in the litter - the number of father's inferred alleles was equal or smaller than two in all loci, probably representing one individual. The analyses in GERUD 2.0 confirmed the results from the mannual counting of alleles, estimating only one probable sire for the three cubs and two possible genotypes for the sire; these are the same genotypes as reported in Figure 1. Therefore we conclude that the three cubs have the same parents. Each cub had originated from a unique oocyte, having distinct genotypes. Moreover, the mother and father shared just five alleles across nine loci, suggesting they are non-relatives.

Our result was similar to previous research testing paternity in wild jaguars: Soares et al. (2006) found two cubs from one litter having the same father in Emas National Park (Central Brazil). Based on these two results, it is possible to hypothesize that males follow the females during the entire estrous period,

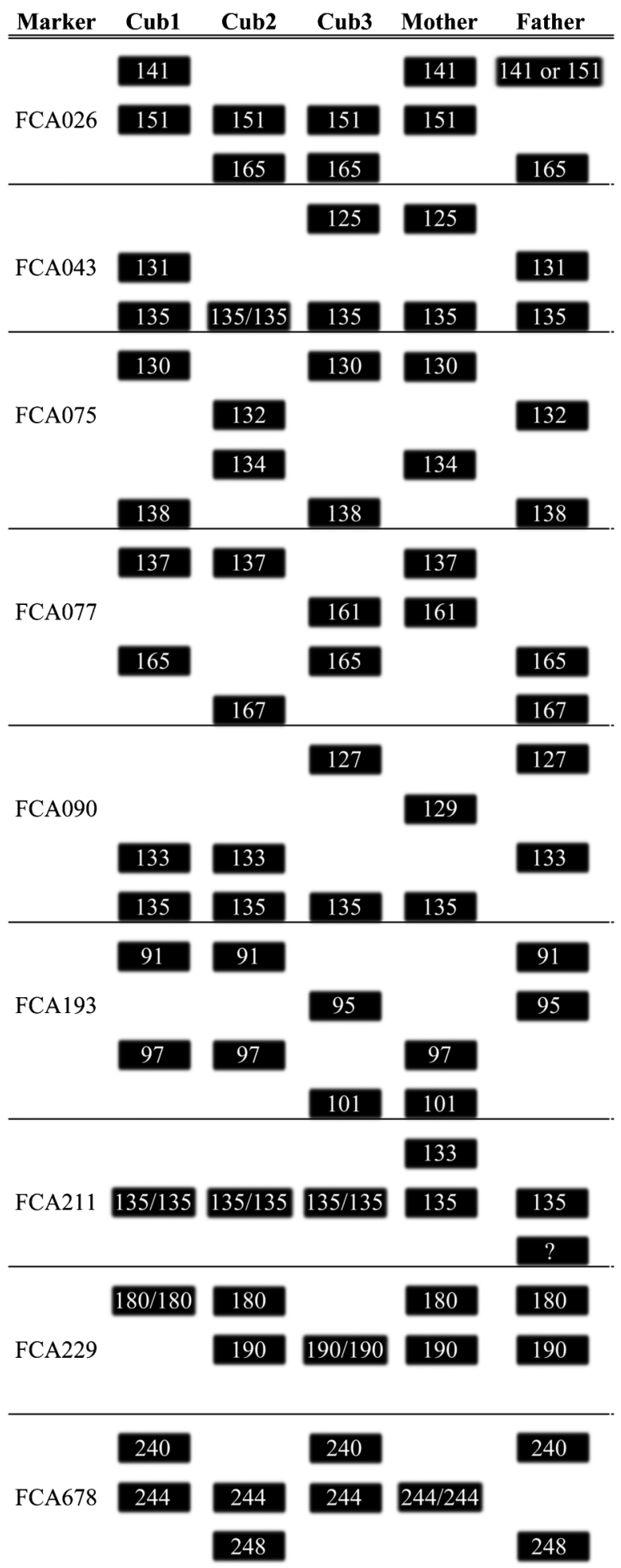

Figure 1. Genotypes of the mother and cubs for each microsatellite locus and father's inferred genotype.

guaranteeing the birth of their cubs. Studies have reported males close to females for at least two days during the mating event (Harmsen 2006, in Harmsen et al. 2010; Sunquist and Sunquist 2002). However this behavior can change in respect to other factors, such as population sex ratio and number of females on estrus at the same time (reproductive seasonality). Natoli et al. 
(2007) also argue that some features of female reproductioninduced ovulation, long ovulation period and delayed ovulation after copulation - can favor multiple copulations and, therefore, generate a mixing of sperm from multiple males.

Generally, female cats mate many times, and several days are necessary to stimulate ovulation (Kleiman \& Eisenberg 1973, Brown 2011). But, there is also a possibility of spontaneous ovulation, and this can vary even among individuals of the same species (Brown 2011). Wildt et al. (1979) found no evidence for spontaneous ovulation in a jaguar-the vesicular follicles gradually regressed during the second half of estrous when the induction was absent. The jaguar estrous period is between 6 to 17 days, with a mean of 12-12.9 days (Sadleir, 1966; Wildt et al., 1979), when the females remain receptive. Theoretically, jaguars can breed the year round (Kleiman \& Eisenberg 1973, Sunquist \& Sunquist 2002), but there is evidence of peak male-fecal androgen concentrations and copulations occurring mainly in the wet season in the Brazilian Southeast and Pantanal (Quigley \& Crawshaw 2002, Morato et al. 2004). Therefore, jaguars have a fairly long estrous period, generally induced ovulation, and, if they do have breeding seasons, males can try to attend to more than one female in the same season, which would expose females that already copulated to other males.

Population sex ration, as mentioned above, is another factor that may induce the presence of multiple paternity, as reported for other felid species. In African lions (Panthera leo), groups with lower male-to-female ratio were significantly more likely to have extra-group paternity, with an overall extragroup paternity in $41 \%$ of the cubs (Lyke et al. 2013). Also, from the 22 litters analyzed by Lyke et al. (2013), four presented multiple paternity and, for each mixed litter, at least one extragroup father was identified. Similarly, Natoli et al. (2007) observed from one multi-male multi-female group (six reproductive females and 14 reproductive males), a percentage of multiple paternity as high as $78 \%$; they concluded that being a dominant male does not guarantee the total control of the receptive females. To the best of our knowledge, cases of multiple paternity were described only for social cats.

In jaguars, several studies found a major proportion of males in populations (varying from $4: 1$ to $15: 1$ ), which could enhance the proportion of multiple paternity in the litters due to the increased competition for females. However, estimated sex ratios in natural jaguar populations may be inaccurate for reasons usually related to methodological sampling biases induced by jaguar behavior, such as: males having bigger home ranges, the higher overlap between male home ranges, and the smaller rate of females captured (Harmsen et al. 2010). Palomares et al. (2012) observed more males than females in six study areas even after identifying individuals from fecal samples, and they attributed this result to the increased use of the sampled routes by males. Aware of these biases induced by sex-specific behavior, Sollmann et al. (2011) used sex-specific capture-recapture models and found a sex ratio of one male to four females, a result that, according to the authors, should be interpreted cautiously. To perform a population viability analysis, studies have used a sex ratio of 1:1 (Desbiez et al. 2012, Miller 2013). Therefore the population sex ratio for jaguars is difficult to estimate and there is no consensus among studies.

In addition to the paternity test, we observed a female jaguar attracting males and becoming pregnant at approximately $60 \mathrm{Kg}$ ( $\approx 3.5$ years) in the central Amazon. This observation, added to previous and future reports, is important due to the poor knowledge regarding the age of sexual maturity in the jaguar (Quigley \& Crawshaw 2002). Here, we reinforce the conclusions of Carrillo et al. (2009), who observed pregnancy while radiotracking a $60 \mathrm{~kg}$ female in Costa Rica, and from Wildt et al. (1979), who registered the first behavioral estrus at 29.5 months of age in a captive female. Also, Seymour (1989) and Sunquist and Sunquist (2002) state, based on few studies, that females become sexually mature at 2 years old and males at 3 years.

Moreover, we registered three cubs in one gestation, an event that is not unheard of, but is relatively rare. The female jaguar give birth to an average of two cubs per gestation, with a gestation of approximately four months (Sadleir 1966). In Belize, from 23 observations, 52\% represented two cubs, 35\% one cub and only 13\% were three cubs (Rabinowitz 1986). Carrillo et al. (2009) reported the birth of one cub, Scognamillo et al. (2003) and Soares et al. (2006) two cubs, and Quigley and Crawshaw (2002) observed one female having two cubs in one gestation and one cub in other. The interval between births is 22-24 months, and in 18-24 months the juveniles leave the mother (Quigley \& Crawshaw 2002, Carrillo et al. 2009).

In this study, we present an overview about several aspects of jaguar reproduction and report for the first time, to our knowledge, the pregnancy and paternity test of a wild Amazonian jaguar. Also, this work is a result of an opportunity generated by a fatality and equivalent opportunities should be taken by scientists to gather more information about the jaguar's reproduction and behavior. The accumulation of small reports can lead to increasingly accurate conclusions about this poorly studied animal.

\section{Acknowledgments}

The authors are grateful to the Wildlife Core (NUFAS) from the Brazilian Institute of Environment and Renewable Natural Resources (IBAMA) for sending the jaguar individual to be analyzed at the Universidade Federal do Amazonas. GMP was supported by a National Council for Scientific and Technological Development (CNPq) fellowship and IPF by a Bolsa de Pesquisa scholarship from CNPq during the study. GMP and IPF acknowledges the members of the Laboratory of Evolution and Animal Genetics (LEGAL), especially Julia T. Verba and Rupert A. Collins for reviewing previous versions of the manuscript.

\section{References}

ABREU, D.K., RODRIGUES, E.A.F., MONTEIRO, J.M., FRANCIOLLI, L., COSTOLA-SOUZA, C., ROBALLO, K.C.S., AMBRSIO, C.E., \& MIGLINO, M.A. 2011. Estudo microscópico e macroscópico, com enfoque radiográfico e de alizarina, no desenvolvimento embrionário e fetal de gatos domésticos (Felis catus) em diferentes idades gestacionais. Pesquisa Veterinária Brasileira. 31:5766, http://dx.doi.org/10.1590/S0100-736X2011001300010

AZEVEDO, M.H.F., PAULA, T.A.R., DA MATTA,, S.L.P, FONSECA, CC, \& NEVES, M.T.D. 2006. Morfometria testicular e o túbulo seminífero da onça-pintada (Panthera onca) adulta. Ceres. 53(307):374-381.

BROWN, J.L. 2011. Female reproductive cycles of wild female felids. Animal reproduction science. 124(3)-(4):155-62 Available at http:// www.ncbi.nlm.nih.gov/pubmed/20888156 (verified 19 June 2013), http://dx.doi.org/10.1016/j.anireprosci.2010.08.024

CARRILLO, E., SAENZ, J., \& FULLER, T. 2009. Interbirth interval of a free-ranging jaguar. Mammalian Biology - Zeitschrift für 
Säugetierkunde. 74(4):319-320 Available at http://linkinghub. elsevier.com/retrieve/pii/S1616504709000330 (verified 27 June 2013), http://dx.doi.org/10.1016/j.mambio.2009.02.005

COSTA, L.P., LEITE, Y.L.R., MENDES, S.L., \& DITCHFIELD, A.D. 2005. Mammal Conservation in Brazil. Conservation Biology. 19(3):672-679, http://dx.doi.org/10.1111/j.1523-1739.2005.00666.x

COSTA, D.S., PAULA, T.A.R., \& DA MATTA SLP. 2006. Cat, Cougar, and Jaguar Spermatogenesis: a Comparative Analysis. Brazilian Archives of Biology and Technology. 49(5):725-731, http://dx.doi.org/10.1590/S1516-89132006000600006

CULVER, M., DRISCOLL, C., EIZIRIK, E., \& SPONG, G. 2010. Genetic applications in wild felids. In MACDONALD, D.W., LOVERIDGE, A.J. (eds.), Biology and Conservation of Wild Felids. Oxford University Press. p. 762.

DESBIEZ, A.L.J., TRAYLOR-HOLZER, K., LACY, B., BEISIEGEL, B.M., BREITENMOSER-WRSTEN, C., SANA, D.A., MORAES JR, E.A., CARVALHO JR, E.A.R., LIMA, F., BOULHOSA, RLP., DE PAULA RC., MORATO, RG., CAVALCANTI, SMC., \& DE OLIVEIRA TG.. 2012. Population Viability Analysis of jaguar populations in Brazil. Cat News. 7:35-37.

DEWOODY, J.A., SCHUPP, J., KENEFIC, L., BUSCH, J., MURFITT, L., \& KEIM, P. 2004. Universal method for producing ROX-labeled size standards suitable for automated genotyping. Biotechniques. 37:348-352.

GARLA, R.C., SETZ, E.Z.F., \& GOBBI, N. 2001. Jaguar (Panthera onca) Food Habits in Atlantic Rain Forest of Southeastern Brazil. Biotropica. 33(4):691-696, http://dx.doi.org/10.1111/j.1744-7429. 2001.tb00226.x

HARMSEN, B.J., FOSTER, R.J., SILVER, S.C., OSTRO, L.E.T., \& DONCASTER, C.P. 2010. The ecology of jaguars in the Cockscomb Basin Wildlife Sanctuary, Belize. In MACDONALD, D.W., LOVERIDGE, A.J. (eds.), Biology and Conservation of Wild Felids. Oxford University Press. p. 762.

JEDRZEJEWSKI, W., ABARCA, M., VILORIA, Á., CERDA, H., LEW, D., TAKIFF, H., ABADA, E., VELOZO, P., \& SCHMIDT, K. 2011. Jaguar Conservation in Venezuela against the backdrop of current knowledge on its biology and evolution. Interciencia. 36(12):954-966.

JONES, A.G. 2005. Gerud 2.0: a computer program for the reconstruction of parental genotypes from half-sib progeny arrays with known or unknown parents. Molecular Ecology Notes. 5:708711, http://dx.doi.org/10.1111/j.1471-8286.2005.01029.x

KLEIMAN, D.G., \& EISENBERG, J.F. 1973. Comparisons of canid and felid social systems from an evolutionary perspective. Animal behaviour. 21:637-659Available at http://www.ncbi.nlm.nih.gov/ pubmed/4798194.

LYKE, M.M., DUBACH, J., \& BRIGGS, M.B. 2013. A molecular analysis of African lion (Panthera leo) mating structure and extragroup paternity in Etosha National Park. Molecular ecology. 22:2787-2796Available at http://www.ncbi.nlm.nih.gov/pubmed/ 23495802 (verified 18 June 2013).

MACDONALD, D.W., MOSSER, A., \& GITTLEMAN, J.L. 2010. Felid society. In MACDONALD, D.W., LOVERIDGE, A.J. (eds.), Biology and Conservation of Wild Felids. Oxford University Press. p. 762.

MENOTTI-RAYMOND, M., DAVID, V.A., LYONS, L.A., SCHFFER, A.A., TOMLIN, J.F., HUTTON, M.K., \& OBRIEN, S.J. 1999. A genetic linkage map of microsatellites in the domestic cat (Felis catus). Genomics. 57:9-23, http://dx.doi.org/ 10.1006/geno.1999.5743

MILLER, P.S. 2013. Population Viability Analysis for the Jaguar (Panthera onca) in the Northwestern Range.

MORATO, R.G., \& BARNABE, R.C. 2002. Potencial de técnicas reproductivas para la conservación del jaguar. In MEDELLN, R.A., EQUIHUA, C., CHETKIEWICZ, C.L.B., CRAWSHAW, P.G., RABINOWITZ, A., REDFORD, K.H., ROBINSON, J.G., SANDERSON, E.W., TABER, E.W. (eds.), El jaguar en el nuevo milenio. Fondo de Cultura Economica y la Universidad Nacional Autonoma de Mexico y Wildlife Conservation Society, Mexico. p. $33-43$.

MORATO, R.G., VERRESCHI, I.T.N., GUIMARES, M.A.B.V, CASSARO, K., PESSUTI, C., \& BARNABE, R.C. 2004. Seasonal variation in the endocrine-testicular function of captive jaguars (Panthera onca). Theriogenology. 61(7)-(8):1273-81 Available at http://www.ncbi.nlm.nih.gov/pubmed/15036961(verified 30 May 2013), http://dx.doi.org/10.1016/j.theriogenology. 2003.07.011

NATOLI, E., SCHMID, M., SAY, L., \& PONTIER, D. 2007. Male Reproductive Success in a Social Group of Urban Feral Cats (Felis catus L.). Ethology. 113:283-289 Available at http://doi.wiley.com/ 10.1111/j.1439-0310.2006.01320.x (verified 12 July 2013), http:// dx.doi.org/10.1111/j.1439-0310.2006.01320.x

PALOMARES, F., ROQUES, S., CHVEZ, C., SILVEIRA, L., KELlER, C., SOLLMANN, R., DO Prado D.M., TORRES, PC., ADRADOS, B, GODOY, JA, JCOMO, A.T.A, TRRES, N.M., FURTADO, M.M., \& LPEZ-BAO, J.V. 2012. High proportion of male faeces in jaguar populations. PloS one. 7(12):e52923 Available at http://www.pubmedcentral.nih.gov/articlerender.fcgi?artid $=3532461 \&$ tool $=$ pmcentrez\&rendertype $=$ abstract (verified 29 May 2013), http://dx.doi.org/10.1371/journal. pone. 0052923

PAZ, R.C.R., ZUGE, R.M., \& BARNABE, V.H. 2007. Frozen Jaguar (Panthera onca) sperm capacitation and ability to penetrate zona free hamster oocytes. Brazilian Journal of Veterinary Research and Animal Science. 44(5):337-344.

QUIGLEY, H.B., \& CRAWSHAW, P.G. 2002. Reproducción, crecimiento y dispersión del Jaguar en la región del Pantanal de Brasil. In Medellín, R.A., EQUIHUA, C, CHETKIEWICZ, C.L.B., CRAWSHAW, P.G., RABINOWITZ, A., REDFORD, K.H., ROBINSON, J.G., SANDERSON, E.W., TABER, E.W. (eds.), El jaguar en el nuevo milenio. Fondo de Cultura Economica y la Universidad Nacional Autonoma de Mexico y Wildlife Conservation Society, Mexico. p. 289-302.

RABINOWITZ, A.R. 1986. Jaguar. Struggle and triumph in the jungles of Belize. Arbor House, New York.

RABINOWITZ, A.R., \& NOTTINGHAM, B.G. 1986. Ecology and behaviour of the Jaguar (Panthera onca) in Belize, Central America. Journal of Zoology. 210:149-159, http://dx.doi.org/ 10.1111/j.1469-7998.1986.tb03627.x

SADLEIR, R.M.F.S. 1966a. Notes on reproduction in the larger Felidae. International Zoo Yearbook. 6:184-187, http://dx.doi.org/ 10.1111/j.1748-1090.1966.tb01746.x

SADLEIR, R.M.F.S. 1966b. Notes on reproduction in the larger Felidae (CORDANI, U.G., MILANI, E.J., THOMAZ-FILHO, A. and DE, D., CAMPOS, A. Eds.). International Zoo Yearbook. 6:453-480.

SCHUELKE, M. 2000. An economic method for the fluorescent labeling of PCR fragments. Nature Biotechnology. 18(2):233-234, http://dx.doi.org/10.1038/72708

SCOGNAMILLO, D., MAXIT, I.E., SUNQUIST, M., \& POLISAR, J. 2003. Coexistence of jaguar (Panthera onca) and puma (Puma concolor) in a mosaic landscape in the Venezuelan llanos. Journal of Zoology. 259:269-279 Available at http://doi.wiley.com/10.1017/ S0952836902003230 (verified 29 May 2013), http://dx.doi.org/ $10.1017 / \mathrm{S} 0952836902003230$

SEYMOUR, K.L. 1989. Panthera onca. Mammalian Species. 340:1-9, http://dx.doi.org/10.2307/3504096

SOARES, T.N., TELLES, M.P.C., RESENDE, L.V., SILVEIRA, L., JCOMO, A.T.A., MORATO, R.G., DINIZ-FILHO, J.A.F., EIZIRIK, E., BRONDANI, R.P.V \& BRONDANI, C. 2006. Paternity testing and behavioral ecology: A case study of jaguars (Panthera onca) in Emas National Park, Central Brazil. Genetics and Molecular Biology. 29(4):735-740, http://dx.doi.org/10.1590/ S1415-47572006000400025 
SOLLMANN, R., FURTADO, M.M., GARDNER, B., HOFER, H., JCOMO, A.T.A., TRRES, N.M., \& SILVEIRA, L. 2011. Improving density estimates for elusive carnivores: Accounting for sex-specific detection and movements using spatial capturerecapture models for jaguars in central Brazil. Biological Conservation. 144:1017-1024 Available at http://linkinghub. elsevier.com/retrieve/pii/S0006320710005197 (verified 29 May 2013), http://dx.doi.org/10.1016/j.biocon.2010.12.011

SUNQUIST, M.E. 1981. The Social Organization of Tigers (Panthera tigris) in Royal Chitawan National Park, Nepal. Smithsonian Contributions to Zoology. 336:1-98Available at http://si-pddr.si. edu/dspace/handle/10088/6316.
SUNQUIST, M., \& SUNQUIST, F. 2002. Wild Cats of the World. University of Chicago Press.

SWANSON, W.F. 2006. Application of assisted reproduction for population management in felids: the potential and reality for conservation of small cats. Theriogenology. 66:49-58 Available at http://www.ncbi.nlm.nih.gov/pubmed/16650889 (verified 19 July 2013), http://dx.doi.org/10.1016/j.theriogenology.2006.03.024

WILDT, D.E., PLATZ, C.C., CHAKRABORTY, P.K., \& SEAGER, S.W.J. 1979. Oestrous and ovarian activity in a female jaguar (Panthera onca). Journal of Reproduction and Fertility. 56:555558, http://dx.doi.org/10.1530/jrf.0.0560555 